\title{
Seminal Vesicle Squamous Cell Carcinoma
}

National Cancer Institute

\section{Source}

National Cancer Institute. Seminal Vesicle Squamous Cell Carcinoma. NCI Thesaurus.

Code C161634.

An extremely rare squamous cell carcinoma that arises from the seminal vesicle.

Glandular formation and mucin secretion are absent. 